\title{
Do processing time and storage of sputum influence quantitative bacteriology in bronchiectasis?
}

\author{
Correspondence \\ Maeve P. Murray \\ maevemurray@hotmail.com
}

Received 13 October 2009

Accepted 20 March 2010

\author{
Maeve P. Murray, ${ }^{1}$ Catherine J. Doherty, ${ }^{2}$ John R. W. Govan ${ }^{2}$ \\ and Adam T. Hill ${ }^{1}$
}
${ }^{1}$ Department of Respiratory Medicine, Royal Infirmary of Edinburgh, 51 Little France Crescent, Old Dalkeith Road, Edinburgh EH16 4SA, UK
${ }^{2}$ Cystic Fibrosis Group, Centre for Infectious Diseases, School of Medicine and Veterinary Medicine, The Chancellor's Building, University of Edinburgh, Edinburgh EH16 4SB, UK

\begin{abstract}
This study aimed to establish whether the bacterial density of spontaneous sputum is affected by the time and mode of sample storage. Ten patients with bronchiectasis collected all sputum expectorated over $45 \mathrm{~min}$. The samples were aliquoted and processed at $25^{\circ} \mathrm{C}$ for qualitative and quantitative bacteriology at 1, 2, 4 and $6 \mathrm{~h}$ from expectoration. Further aliquots were stored at $25{ }^{\circ} \mathrm{C}, 4^{\circ} \mathrm{C}$ and $-20{ }^{\circ} \mathrm{C}$ for 24 and $48 \mathrm{~h}$ prior to processing. The species present was identified and median (interquartile range) sputum $\log _{10}$ bacterial density (c.f.u. $\mathrm{ml}^{-1}$ ) calculated. All samples cultured grew Pseudomonas aeruginosa and for two patients Staphylococcus aureus additionally grew for all samples. There was no significant difference in $P$. aeruginosa density in samples processed at $1,2,4$ and $6 \mathrm{~h}$ following expectoration [8.2 (7.8-8.3) c.f.u. $\mathrm{ml}^{-1}, 8.0$ (7.88.3) c.f.u. $\mathrm{ml}^{-1}, 8.0(7.9-8.2)$ c.f.u. $\mathrm{ml}^{-1}, 8.1$ (7.9-8.2) c.f.u. $\mathrm{ml}^{-1}$, respectively, $\left.P=0.392\right]$.

Storage for 24 and $48 \mathrm{~h}$ at $4{ }^{\circ} \mathrm{C}$ did not significantly change the bacterial load compared with processing at $1 \mathrm{~h}\left[8.03(7.6-8.2)\right.$ c.f.u. $\mathrm{ml}^{-1}, P=0.07$, and $7.96(7.49-8.22)$ c.f.u. $\mathrm{ml}^{-1}, P=0.09$, respectively]. Storage for 24 and $48 \mathrm{~h}$ at $-20{ }^{\circ} \mathrm{C}$ significantly reduced $P$. aeruginosa density [7.1 (6.1-7.7) c.f.u. $\mathrm{ml}^{-1}, P=0.005$, and 6.9 (6.2-7.6) c.f.u. $\mathrm{ml}^{-1}, P=0.008$, respectively]. Storage at $25^{\circ} \mathrm{C}$ for 24 and $48 \mathrm{~h}$ was associated with a significant increase in bacterial load [8.3 (8.1-8.6) c.f.u. $\mathrm{ml}^{-1}, P=0.009$, and $8.4(8.1-8.5)$ c.f.u. $\mathrm{ml}^{-1}, P=0.03$, respectively]. Bacterial density was not affected by storage for up to $6 \mathrm{~h}$ following expectoration at $25{ }^{\circ} \mathrm{C}$; beyond this, storage at $4{ }^{\circ} \mathrm{C}$ is preferred.
\end{abstract}

\section{INTRODUCTION}

Sputum microbiology has a crucial role in both the diagnosis and management of non-cystic fibrosis bronchiectasis (Angrill et al., 2002; Loebinger et al., 2009; Murray \& Hill, 2009). During routine care of patients with pulmonary exacerbations and during multicentre trials of new antimicrobial agents, quantitative bacteriology of sputum samples is used to monitor treatment response and assess the efficacy of therapies (Barker et al., 2000; Drobnic et al., 2005). In the UK, this technique is typically limited to reference laboratories, which often implies a prolonged time period from expectoration to processing as samples are transported to such centres. Appropriate collection, storage and transportation of sputum samples is critical as it may have a direct impact on the recovery of viable organisms. Surprisingly, there appear to have been few studies to investigate the impact of sputum storage on bacterial recovery. The aim of this study was to establish

Abbreviation: HRCT, high resolution computed tomography. whether the total bacterial density recovered and the bacterial species identified from spontaneous sputum is affected by the mode of storage and time of processing of up to $48 \mathrm{~h}$ from expectoration.

\section{METHODS}

This was a prospective study of patients with clinically stable noncystic fibrosis bronchiectasis that were chronically colonized with Pseudomonas aeruginosa (May-June 2009). The study was approved by the Lothian Research Ethics Committee. The primary outcome was sputum $P$. aeruginosa density $\left(\log _{10}\right.$ c.f.u. $\left.\mathrm{ml}^{-1}\right)$.

\section{Patients.}

Patients were recruited from the Bronchiectasis Clinic, Royal Infirmary of Edinburgh, Scotland, UK. Inclusion criteria were: a radiological diagnosis of bronchiectasis by high resolution computed tomography (HRCT) chest scan according to the features described by Naidich et al. (1982), chronic sputum expectoration, chronically infected with $P$. aeruginosa (defined as culture of $P$. aeruginosa from sputum on at least three consecutive occasions in the preceding 12 months when clinically stable), clinically stable disease (defined as no 
requirement for antibiotics in the 4 weeks preceding study entry). Exclusion criteria were: current or ex-smokers of $\leqslant 2$ years or exsmokers with a history of $\geqslant 10$ pack years of smoking and emphysema shown on HRCT; on long-term oral or inhaled antibiotics.

\section{Sputum collection.}

Patients were instructed to perform cycles of two to three forced expiratory techniques (huffs) followed by coughing to enhance expectoration over a 45 min period. All sputum expectorated was collected in a sterile transparent container.

\section{Sputum storage.}

Each sputum sample was immediately aliquoted into 10 separate sterile containers. Qualitative and quantitative bacteriology was then performed at the following time points: 1, 2, 4 and $6 \mathrm{~h}$ from the start of expectoration (Fig. 1). The samples were stored at room temperature $\left(25^{\circ} \mathrm{C}\right)$ throughout these time points. The other aliquoted samples were handled as follows: two samples were immediately stored at $4{ }^{\circ} \mathrm{C}$ for 24 and $48 \mathrm{~h}$; two samples were immediately stored at $-20{ }^{\circ} \mathrm{C}$ for 24 and $48 \mathrm{~h}$; two samples were stored at room temperature $\left(25^{\circ} \mathrm{C}\right)$ for 24 and $48 \mathrm{~h}$ (Fig. 1).

\section{Sputum processing.}

Each sample was confirmed to be a valid sputum sample suitable for processing if there were $>25$ polymorphonuclear leukocytes and $<10$ squamous cells present on Gram stain on low power $(\times 100)$ magnification (Gleckman et al., 1988). At the designated time for processing, samples were prepared for qualitative and quantitative bacteriology as described by Pye et al. (1995). Briefly, sputum was homogenized and liquified using an equal volume of $0.1 \%$ DTT, and serially diluted using sterile $0.9 \%$ saline to achieve dilution factors of $10^{-1}$ to $10^{-4}$. Cetrimide (Difco) Pseudomonas isolation agar and blood agar plates were inoculated with $100 \mu \mathrm{l}$ sample. These were incubated at $37{ }^{\circ} \mathrm{C}$ for $24 \mathrm{~h}$. Colonies were then counted to determine the sputum $P$. aeruginosa density expressed as $\log _{10}$ c.f.u. $\mathrm{ml}^{-1}$. Any other microbial pathogens present were identified and counted. For consistency, all samples were handled, processed and counted by the first author.

\section{Statistics.}

Statistical analysis was performed using SPSS for Windows, version 17 (SPSS) and GraphPad Prism version 5.0 (GraphPad Software). Data are presented as median (interquartile range) values. The BlandAltman technique was used to compare the different storage methods tested. If a difference was identified, the Wilcoxon analysis for two groups was used. A two-tailed $P$ value of $<0.05$ was considered statistically significant.

\section{RESULTS}

\section{Patients}

Ten patients (two male) aged $70(67.2-70.2)$ years with non-cystic fibrosis bronchiectasis and a history of chronic $P$. aeruginosa colonization were recruited. The aetiology of the bronchiectasis was post-infective in five $(50 \%)$, idiopathic in four $(40 \%)$ and inactive allergic bronchopulmonary aspergillosis in one (10\%). Five (3.75-5.25) lobes were involved on HRCT chest scan (for the purposes of this study the lingula was considered a separate lobe) and eight $(80 \%)$ patients had either cystic or varicose dilatation in at least one lobe.

\section{Baseline qualitative sputum bacteriology}

All samples cultured $P$. aeruginosa, of which eight had mucoid species. Two patients additionally had a growth of Staphylococcus aureus identified at baseline and this remained present in all subsequent aliquoted sputum samples. No other organisms were present on culture at any time point for the remaining eight patient samples. The patients with mucoid species had advanced bronchiectasis with five (3.25-5.75) lobes involved, and all had either cystic or varicose dilatation in at least one lobe.

\section{Quantitative sputum bacteriology}

Sputum processed at 1-6 $\mathrm{h}$ from expectoration. There was no significant difference $(P=0.392)$ in $P$. aeruginosa density when processing the sputum at 1, 2, 4 and $6 \mathrm{~h}$ from expectoration (Fig. 2). The mean difference (SD) with $95 \%$

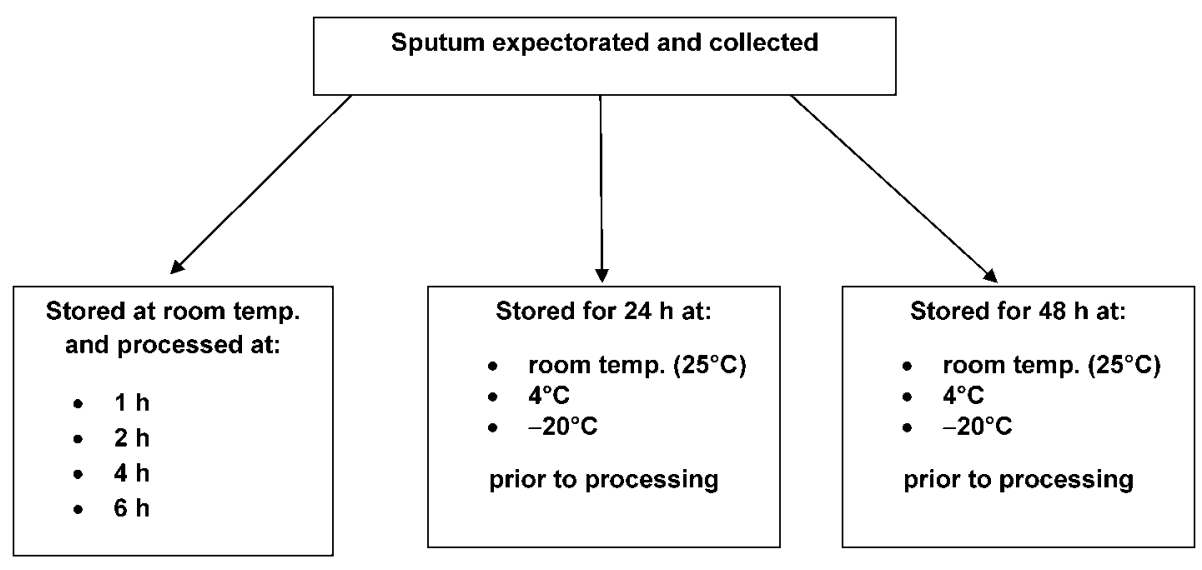

Fig. 1. Method of sputum sample storage and processing. 


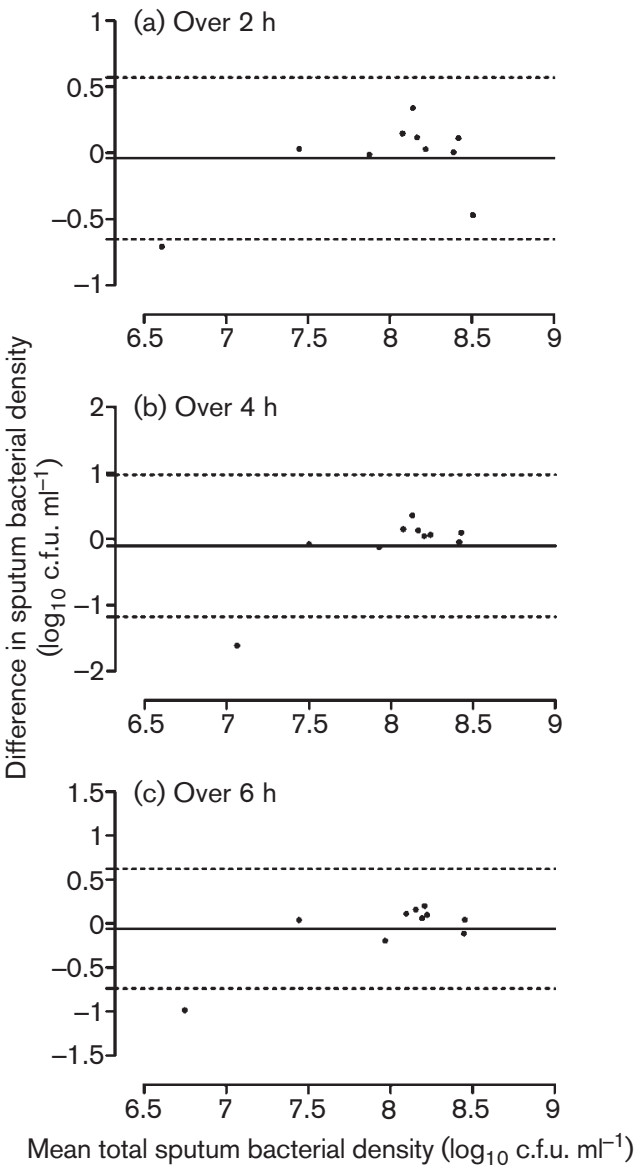

Fig. 2. Bland-Altman plot of sputum bacterial density over (a) 2, (b) 4 and (c) $6 \mathrm{~h}$. The solid lines represent the mean difference between the density at 1, and 2, 4 and $6 \mathrm{~h}$ for (a), (b) and (c), respectively. The perforated lines represent the upper and lower $95 \%$ limits of agreement.

limits of agreement between processing at $1 \mathrm{~h}$ compared with $2 \mathrm{~h}$ was $-0.04(0.31),-0.65$ to 0.57 ; between 1 and $4 \mathrm{~h}$ was $-0.1(0.54),-1.2$ to 0.97 and between 1 and $6 \mathrm{~h}$ was $-0.06(0.35),-0.7$ to 0.6 .

Sputum processed after storage for $24 \mathrm{~h}$. When comparing sputum processed at $1 \mathrm{~h}$ from the start of expectoration with sputum stored for $24 \mathrm{~h}$ at room temperature $\left(25^{\circ} \mathrm{C}\right)$, there was a small but significant increase in $P$. aeruginosa density at $24 \mathrm{~h}$ (Fig. 3). There was no significant difference in $P$. aeruginosa density between sputum processed at $1 \mathrm{~h}$ with sputum stored for $24 \mathrm{~h}$ at $4{ }^{\circ} \mathrm{C}$ prior to processing. When comparing sputum processed at $1 \mathrm{~h}$ with sputum processed after storage at $-20{ }^{\circ} \mathrm{C}$ for $24 \mathrm{~h}$, there was a significant reduction in Pseudomonas density. The mean difference (SD) with $95 \%$ limits of agreement between processing at $1 \mathrm{~h}$ compared with $24 \mathrm{~h}$ storage at room temperature $\left(25^{\circ} \mathrm{C}\right)$ was 0.38 (0.39), -0.39 to 1.16 ; between 1 and $24 \mathrm{~h}$ at $4{ }^{\circ} \mathrm{C}$ was

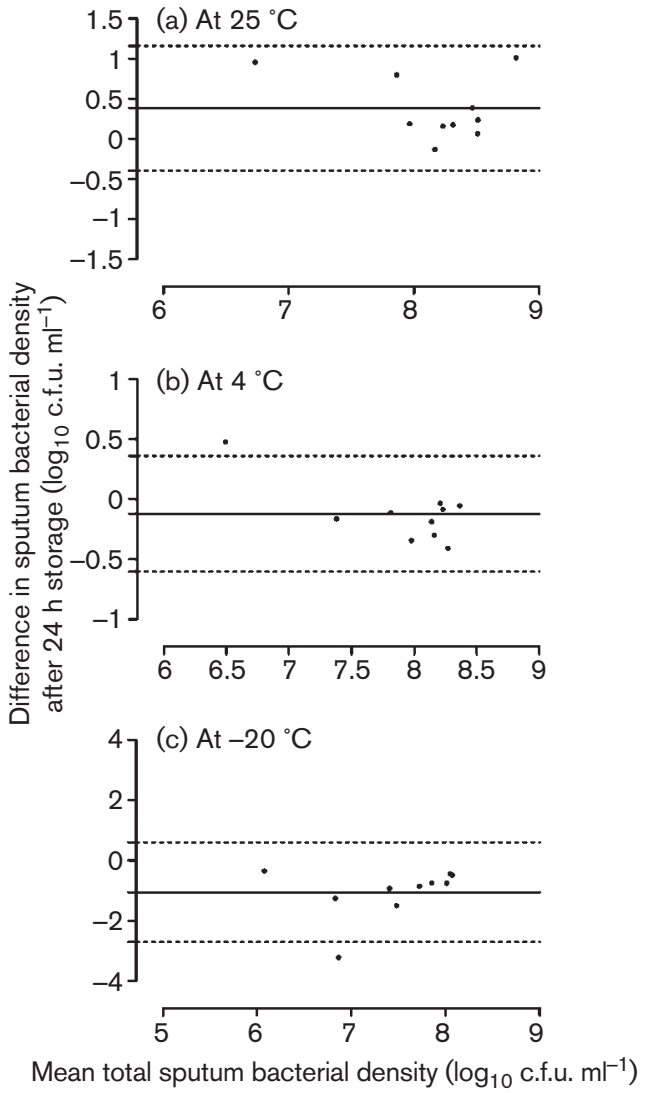

Fig. 3. Bland-Altman plot of sputum bacterial density after $24 \mathrm{~h}$ storage at (a) 25 , (b) 4 and (c) $-20{ }^{\circ} \mathrm{C}$. The solid lines represent the mean difference between the density at $1 \mathrm{~h}$ and after storage for $24 \mathrm{~h}$ at 25,4 and $-20{ }^{\circ} \mathrm{C}$ for (a), (b) and (c), respectively. The perforated lines represent the upper and lower $95 \%$ limits of agreement.

$-0.12(0.24),-0.6$ to 0.36 ; and between 1 and $24 \mathrm{~h}$ at $-20{ }^{\circ} \mathrm{C}$ was $-1.05(0.84),-2.7$ to 0.60 .

Sputum processed after storage for $\mathbf{4 8} \mathrm{h}$. When comparing sputum processed at $1 \mathrm{~h}$ from the start of expectoration with sputum stored for $48 \mathrm{~h}$ at room temperature $\left(25^{\circ} \mathrm{C}\right)$, there was a significant increase in $P$. aeruginosa density at $48 \mathrm{~h}$ (Fig. 4). There was no significant difference between sputum processed at $1 \mathrm{~h}$ with sputum stored for $48 \mathrm{~h}$ at $4{ }^{\circ} \mathrm{C}$ prior to processing. When comparing sputum processed at $1 \mathrm{~h}$ with sputum processed after storage at $-20{ }^{\circ} \mathrm{C}$ for $48 \mathrm{~h}$, there was a significant reduction in $P$. aeruginosa density. The mean difference (SD) with $95 \%$ limits of agreement between processing at $1 \mathrm{~h}$ compared with $48 \mathrm{~h}$ storage at room temperature $\left(25^{\circ} \mathrm{C}\right)$ was 0.37 (0.51), -0.64 to 1.38 ; between 1 and $48 \mathrm{~h}$ at $4{ }^{\circ} \mathrm{C}$ was -0.16 (0.28), -0.72 to 0.40 ; and between 1 and $48 \mathrm{~h}$ at $-20{ }^{\circ} \mathrm{C}$ was -1.07 (0.92), -2.88 to 0.74 .

Mucoid $\boldsymbol{P}$. aeruginosa samples. Samples culturing only mucoid $P$. aeruginosa were analysed $(n=8)$. The median 


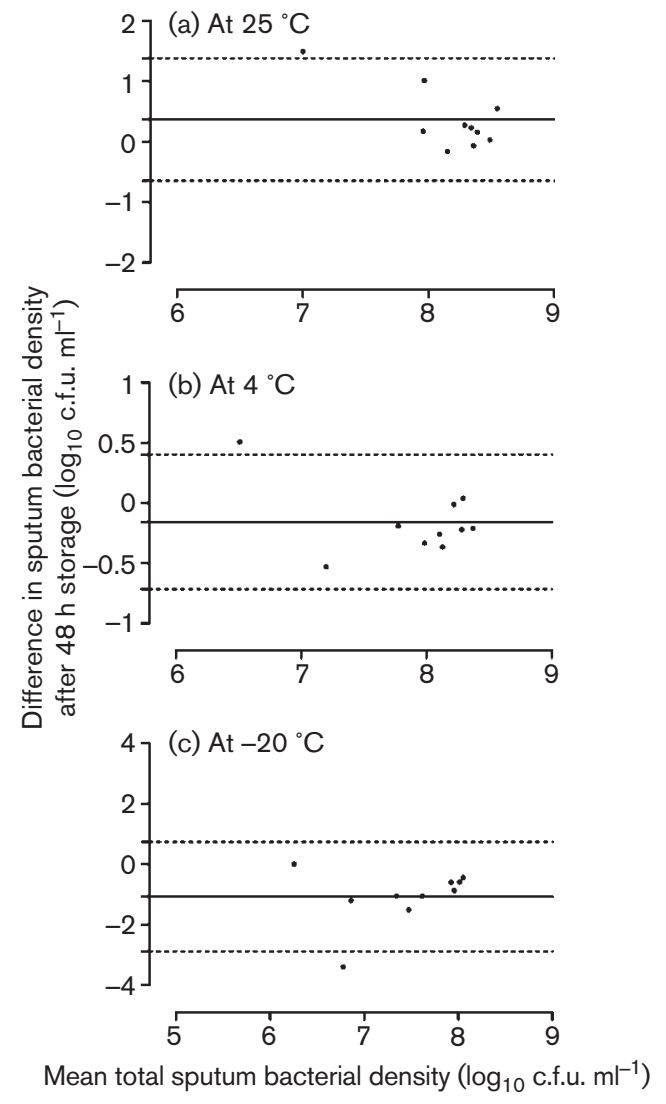

Fig. 4. Bland-Altman plot of sputum bacterial density after $48 \mathrm{~h}$ storage at (a) 25 , (b) 4 and (c) $-20{ }^{\circ} \mathrm{C}$. The solid lines represent the mean difference between the density at $1 \mathrm{~h}$ and after storage for $48 \mathrm{~h}$ at 25,4 and $-20{ }^{\circ} \mathrm{C}$ for (a), (b) and (c), respectively. The perforated lines represent the upper and lower $95 \%$ limits of agreement.

(interquartile range) sputum $\log _{10}$ bacterial density of samples at $1 \mathrm{~h}$ was $8.25(7.94-8.84)$ c.f.u. $\mathrm{ml}^{-1}$. After storage for $24 \mathrm{~h}$ at room temperature $\left(25^{\circ} \mathrm{C}\right)$ the density was slightly higher $8.47(8.12-8.65)$ c.f.u. $\mathrm{ml}^{-1}(P=0.01)$; after $24 \mathrm{~h}$ storage at $4{ }^{\circ} \mathrm{C}$ the density was not significantly different $8.04(7.77-8.19)$ c.f.u. $\mathrm{ml}^{-1}(P=0.16)$ and after $24 \mathrm{~h}$ storage at $-20{ }^{\circ} \mathrm{C}$ the density was lower 7.38 (6.167.78) c.f.u. $\mathrm{ml}^{-1}(P=0.01)$. After storage for $48 \mathrm{~h}$ at room temperature $\left(25^{\circ} \mathrm{C}\right)$, the density was slightly higher 8.44 (8.1-8.49) c.f.u. $\mathrm{ml}^{-1}(P=0.02)$; after $48 \mathrm{~h}$ storage at $4{ }^{\circ} \mathrm{C}$ the density was not significantly different $8.06(7.7-8.25)$ c.f.u. $\mathrm{ml}^{-1}(P=0.26)$ and after $48 \mathrm{~h}$ storage at $-20{ }^{\circ} \mathrm{C}$, the density was lower $7.3(6.40-7.70)$ c.f.u. $\mathrm{ml}^{-1}(P=0.02)$.

\section{DISCUSSION}

This study showed that $P$. aeruginosa density in non-cystic fibrosis bronchiectasis is not affected if sputum is processed within $6 \mathrm{~h}$ following expectoration when stored at room temperature $\left(25^{\circ} \mathrm{C}\right)$. The preferred environment for samples requiring storage for either 24 or $48 \mathrm{~h}$ with no significant change in bacterial density or identity compared with processing within $1 \mathrm{~h}$ is at $4{ }^{\circ} \mathrm{C}$. However, storage of sputum samples for 24 and $48 \mathrm{~h}$ at $-20^{\circ} \mathrm{C}$ significantly reduces $P$. aeruginosa density, while storage at room temperature $\left(25^{\circ} \mathrm{C}\right)$ causes a small but statistically significant increase in density but no change in species identified. Subanalysis of patients with mucoid $P$. aeruginosa alone did not change these findings.

It is widely accepted that sputum samples should be processed as quickly as possible following expectoration to optimize pathogen recovery. This may often be logistically difficult, particularly when quantitative bacteriology is necessary and the sample needs transported to a tertiary centre. This study provides useful evidence for both mode of storage during transportation and appropriate time for processing.

We selected patients known to be colonized with $P$. aeruginosa as it is a common pathogen in non-cystic fibrosis bronchiectasis, and it is associated with more severe disease and as such is frequently the target of antimicrobial agents (Evans et al., 1996; Martinez-Garcia et al., 2007; Wilson et al., 1997). We found a small but statistically significant rise in bacterial density when the sputum was stored at room temperature for 24 and $48 \mathrm{~h}$. In their study of sputum storage, Pye and colleagues did not observe any difference between viable numbers of pathogens retrieved following $24 \mathrm{~h}$ storage at $20{ }^{\circ} \mathrm{C}$ compared with samples processed on the same day of expectoration, [mean (SEM) $1.21 \times 10^{9}(0.35)$ c.f.u. $\mathrm{ml}^{-1}$ for same day samples (exact time of processing from expectoration not specified) versus $1.15 \times 10^{9}(0.5)$ c.f.u. $\mathrm{ml}^{-1}$ for samples stored at $20{ }^{\circ} \mathrm{C}$ for $24 \mathrm{~h}$ ] but their study included multiple pathogens and was not specific for $P$. aeruginosa (Pye et al., 2008).

Our findings for storage at $4{ }^{\circ} \mathrm{C}$ are similar to the study of Wong et al. (1984) of cystic fibrosis paediatric sputum samples, which found no detectable change in the quantitative bacterial load of several different pathogens, including $P$. aeruginosa, after 2 days storage of homogenized sputum at $4{ }^{\circ} \mathrm{C}$. Additionally, in their study Gould et al. (1996) processed sputum samples on the day of receipt in the laboratory, and subsequently stored the processed samples for $48 \mathrm{~h}$ at $4{ }^{\circ} \mathrm{C}$ for repeat qualitative bacteriology and achieved reproducible results in up to $75 \%$ of samples, although the patient population for the samples was not described and quantitative bacteriology was not performed.

These previous studies provided useful information and prompted us to investigate further. Our study is believed to be unique in exploring the effect of sample processing, at varying times on the same day of expectoration as well as up to $48 \mathrm{~h}$ with storage of the raw sample at three different temperatures, on sputum $P$. aeruginosa density in patients with non-cystic fibrosis bronchiectasis. Our study is particularly tailored to the logistics of clinical practice and the development of laboratory guidelines. In both 
primary and secondary care, there is often a delay in transportation of samples to the local laboratory - a previous study found that within an individual hospital the mean time from collection to processing was $2 \mathrm{~h}$, with a range from several minutes to $13 \mathrm{~h}$ (Jacobson et al., 1981). Our findings can reassure the clinician responsible for sample collection that given correct storage conditions, a sputum sample may remain viable and reliably interpreted for its results for Pseudomonas infection up to $48 \mathrm{~h}$ from expectoration if stored at $4{ }^{\circ} \mathrm{C}$. Furthermore, multicentre studies in both cystic fibrosis and non-cystic fibrosis bronchiectasis often utilize quantitative bacterial load as an end point, thus optimum storage and processing of samples for quantitative culture is important (Bilton et al., 2006; Hodson et al., 2002). However, further studies are needed to explore the effect of sample storage and processing time on other pathogenic organisms.

In conclusion, sputum samples from patients with noncystic fibrosis bronchiectasis stored at room temperature and processed up to $6 \mathrm{~h}$ from expectoration can be reliably interpreted for $P$. aeruginosa density. For samples requiring processing beyond this time, the optimum environment for storage is at $4{ }^{\circ} \mathrm{C}$ for up to $48 \mathrm{~h}$. Freezing of sputum at $-20{ }^{\circ} \mathrm{C}$ for 24 and $48 \mathrm{~h}$ has a significantly negative impact on culture of $P$. aeruginosa.

\section{ACKNOWLEDGEMENTS}

Dr Maeve Murray is funded by the Chief Scientist Office, Scotland.

\section{REFERENCES}

Angrill, J., Agusti, C., de Celis, R., Rano, A., Gonzalez, J., Sole, T., Xaubet, A., Rodriguez-Roisin, R. \& Torres, A. (2002). Bacterial colonisation in patients with bronchiectasis: microbiological pattern and risk factors. Thorax 57, 15-19.

Barker, A. F., Couch, L., Fiel, S. B., Gotfried, M. H., llowite, J., Meyer, K. C., O'Donnell, A., Sahn, S. A., Smith, L. J. \& other authors (2000). Tobramycin solution for inhalation reduces sputum Pseudomonas aeruginosa density in bronchiectasis. Am J Respir Crit Care Med 162, 481-485.

Bilton, D., Henig, N., Morrissey, B. \& Gotfried, M. (2006). Addition of inhaled tobramycin to ciprofloxacin for acute exacerbations of
Pseudomonas aeruginosa infection in adult bronchiectasis. Chest 130, 1503-1510.

Drobnic, M. E., Sune, P., Montoro, J. B., Ferrer, A. \& Orriols, R. (2005). Inhaled tobramycin in non-cystic fibrosis patients with bronchiectasis and chronic bronchial infection with Pseudomonas aeruginosa. Ann Pharmacother 39, 39-44.

Evans, S. A., Turner, S. M., Bosch, B. J., Hardy, C. C. \& Woodhead, M. A. (1996). Lung function in bronchiectasis: the influence of Pseudomonas aeruginosa. Eur Respir J 9, 1601-1604.

Gleckman, R., DeVita, J., Hibert, D., Pelletier, C. \& Martin, R. (1988). Sputum gram stain assessment in community-acquired bacteremic pneumonia. J Clin Microbiol 26, 846-849.

Gould, F. K., Freeman, R., Hudson, S., Magee, J., Nelson, D., Stafford, R. \& Sisson, P. R. (1996). Does storage of sputum specimens adversely affect culture results? J Clin Pathol 49, 684-686.

Hodson, M. E., Gallagher, C. G. \& Govan, J. R. (2002). A randomised clinical trial of nebulised tobramycin or colistin in cystic fibrosis. Eur Respir J 20, 658-664.

Jacobson, J. T., Burke, J. P. \& Jacobson, J. A. (1981). Ordering patterns, collection, transport, and screening of sputum cultures in a community hospital: evaluation of methods to improve results. Infect Control 2, 307-311.

Loebinger, M. R., Wells, A. U., Hansell, D. M., Chinyanganya, N., Devaraj, A., Meister, M. \& Wilson, R. (2009). Mortality in bronchiectasis: a long-term study assessing the factors influencing survival. Eur Respir J 34, 843-849.

Martinez-Garcia, M. A., Soler-Cataluna, J. J., Perpina-Tordera, M., Roman-Sanchez, P. \& Soriano, J. (2007). Factors associated with lung function decline in adult patients with stable non-cystic fibrosis bronchiectasis. Chest 132, 1565-1572.

Murray, M. P. \& Hill, A. T. (2009). Non-cystic fibrosis bronchiectasis. Clin Med 9, 164-169.

Naidich, D. P., McCauley, D. I., Khouri, N. F., Stitik, F. P. \& Siegelman, S. S. (1982). Computed tomography of bronchiectasis. J Comput Assist Tomogr 6, 437-444.

Pye, A., Stockley, R. A. \& Hill, S. L. (1995). Simple method for quantifying viable bacterial numbers in sputum. J Clin Pathol 48, 719-724.

Pye, A., Hill, S. L., Bharadwa, P. \& Stockley, R. A. (2008). Effect of storage and postage on recovery and quantitation of bacteria in sputum samples. J Clin Pathol 61, 352-354.

Wilson, C. B., Jones, P. W., O'Leary, C. J., Hansell, D. M., Cole, P. J. \& Wilson, R. (1997). Effect of sputum bacteriology on the quality of life of patients with bronchiectasis. Eur Respir J 10, 1754-1760.

Wong, K., Roberts, M. C., Owens, L., Fife, M. \& Smith, A. L. (1984). Selective media for the quantitation of bacteria in cystic fibrosis sputum. J Med Microbiol 17, 113-119. 